\title{
The Internet, Freedom of Expression and Online Readers' Attention to and Utilization of Online Newspapers' Comment Sections
}

\author{
Allen Nnanwuba Adum \\ Department of Mass Communication, \\ Nnamdi Azikiwe University, Awka, \\ Anambra State, Nigeria \\ Emeka Odogwu \\ Department of Mass Communication, \\ Nnamdi Azikiwe University, Awka, \\ Anambra State, Nigeria \\ Kobimdi Umeh \\ Department of Mass Communication, \\ Nnamdi Azikiwe University, Awka, \\ Anambra State, Nigeria \\ Roseline Chioma Amete \\ Department of Mass Communication, \\ Nnamdi Azikiwe University, Awka, \\ Anambra State, Nigeria
}

\begin{abstract}
There is speculation that the exposure of the contents of online newspapers satisfies readers' need for information and slows down the drive for the print versions. This study examined readers' motivations towards reading online newspapers and whether they commented after reading. The study employed descriptive survey method in which questionnaire was administered to a randomly selected sample of 400 online newspaper readers. The findings demonstrated a high overall motivation level of the readers towards reading online version of newspapers. A further analysis of the findings revealed that readers were motivated to read online versions of newspapers because they had access to the internet. Also, readers were motivated to read online versions of newspapers because theyare interactive and provided timely updates. The study concluded that online newspapers were gaining popularity in the newspaper industry. Therefore, newspaper publishers should strategize ways to fully regulate and moderate online discussions on online newspapers' comment sections.
\end{abstract}

Keyword: Internet, freedom of expression, online readers, newspaper comment section

DOI: $10.7176 / \mathrm{NMMC} / 81-07$

Publication date:June $30^{\text {th }} 2019$

\section{Introduction}

Against the backdrop of the changing information environment, emerging communication technologies have altered the landscape of information production and distribution in significant ways (Shirky, 2008); straining and at times displacing the traditional role of journalism to inform the public (see, for example, Tumber, 2001). Mainstream news organizations, no longer having unique access to political information and the advantage of distribution, are experimenting with ways to exploit new technologies to reinvigorate journalism and address contemporary needs (Zamith, 2008). Interactive technologies have opened up new ways of incorporating user generated content within news context.

In particular, an important online feature is the invitation for readers to comment on newspaper content. By offering the opportunity for lay citizens to think about and contribute their perspectives, opinions or expertise to journalistic content, the newspaper is opening up an opportunity for promoting public deliberation. Such media have been received with a good deal of caution (Hermida \& Thurman, 2007, Tumber, 2001). While concerns as to the tone, accuracy or partisanship of much of the political information produced through emerging sites are warranted, the interactive technologies can enable journalists to offer new avenues for citizen participation in the political process. Indeed scholars have been inquiring about the potential of online journalism to employ interactive features in a way that may promote citizen participation and engagement (Schultz, 1999; Roseberry, 2005; Nip, 2006). 
The Internet is today one of the most effective means of communication as a new mass medium and a forceful one too, which has become an integral part of mass media. It is not only a mass medium, but is also a global medium with a potential to reach everyone on the globe (Ohiagu, 2011). The Internet has increased competition for newspapers and revised the way news is distributed. Indirectly, it has influenced advertising trends, readers' behavior and the rise of disruptive technologies. As a result, newspapers have been forced to integrate with the web and now approximately $80 \%$ of newspaper publishers have integrated web and print operation (Patel, 2010). Over the past ten years an increasing number of news websites provide readers the opportunity to post comments on an article and thereby publishing their personal opinions. Newspapers are today blending into what is now considered a single system of interrelated systems (Internet). The influence of the Internet could be readily noticed in the online newspaper phenomenon that has greatly increased the accessibility of people to information services (Patel, 2010).

Due to digital technologies, audiences are becoming more and more active participants in public communication, in a way that means that media producers can no longer expect to operate within an exclusive professionalized enclave (Gurevitchet al., 2009: 168-169). The interest in audience participation is certainly not a new trend or phenomenon, but the rise of new modes of participation enabled by new technologies has provided a leap forward in the inclusion of the audience in public communication mediated by conventional media outlets. This tendency goes along with the notions of a democratic role and public service inherent to the journalistic activity.

Among the many genres of audience participation generated by the incorporation of Internet into traditional media, readers' comments in news are the most widely used in online news sites (Reich, 2011: 97; Noci, 2012: 86; Zamith \& Lewis, 2014: 2). At the same time, they are one of most common forms of citizen engagement online, with great potential for public discourse (Weber, 2014: 941), giving the public a medium for expressing their perspectives on current issues (Henrich \& Holmes, 2013: 1) and on matters of public concern. Readers' comments can be therefore understood as civic forums, where citizens exchange ideas and where civic talk can take place.

The Internet for the first time entirely made possible the fulfillment of the Article 19 of the Universal Declaration - "Everyone has the right to freedom of opinion andexpression; this right includes freedom to hold opinions without interference and to seek,receive and impart information and ideas through any media and regardless offrontiers." On the Internet, everybody is, even unconsciously, sending or receiving information, sharing idea and changing views.

Whereas traditional media readers were limited to writing letters to the editor, an online version of such public forum is available to online news media readers. They can immediately publish their opinions below online news texts. Many are familiar with the comments section to online news. As implemented by most online newspapers, the feature is relatively straightforward, allowing readers to submit their voice - opinion, perspective, expertise to content written by professional journalists. Generally, comments are submitted via a form available at the end of an article. The format may or may not require a reader to register with a news site and usually does not require the commenter to use their real name (Hermida \& Thurman, 2007), though the individual's user name is posted alongside their comment. Varying language is used to elicit comments, including "your turn" (TCPalm.com), "in your voice" (DesMoinesRegister.com), "talk back" (Haaretz.com), or "share your thoughts" (Nytimes.com). In addition to commenting on news stories, many newspapers also elicit comments to editorials and commentary. At the same time, the inclusion of user generated content poses certain risks to newspapers.

Anonymity, lack of moderation, and minimal censorship may lead to inappropriate use of language thereby impeding substantive and constructive discussion. Comments may also elicit uninformed opinion or inaccurate information that may mitigate upon productive problem solving process and at the extreme case may harm the newspaper's reputation (Hermida \& Thurman, 2009).

Also, the possibilities of interactivity have also increased the likelihood that hate speech, which is commonly defined as any form of expression that is directed at objects of prejudice that perpetrators use to wound and denigrate their recipient, might appear among news websites' comments (Erjavec, PolerKovacic, 2012a).

There exists a line though between those that believe in the platform (the Internet) and those who do not due to its credibility and anonymity issues, thus raising a question mark on one's freedom of expression even when included in the Human rights. And as far as the belief goes, it bothers back on why newspaper houses still inculcate as well as encourage online readers' comment section and why some readers comment and others do not or at worse, why some do not read the news stories online but read the comments and comment thereof or choose not to. These are what the work aims to unravel. 


\section{Aims of study}

This study looked at the Internet as a platform that encourages freedom of expression without restrictions and the inculcation of this platform by traditional newspaper houses for online newspaper sites. It sought to establish the level of attention accorded these sites by online readers and their motivationsfor reading online newspapers. To this end, the study sought to answer the following questions:

- Does the right to Freedom of Expression cause internet users to freely express themselves?

- Do online readers read online newspapers?

- Do online readers comment after reading online newspapers?

- Are online readers motivated to comment by others' comments?

\section{Literature Review}

The Internet is the global system of interconnected computer networks that use the Internet protocol suite (TCP/IP) to link billions of devices worldwide. It is a network of networks that consists of millions of private, public, academic, business, and government networks of local to global scope, linked by a broad array of electronic, wireless, and optical networking technologies. The Internet carries an extensive range of information resources and services, such as the inter-linked hypertext documents and applications of the World Wide Web (WWW), electronic mail, telephony, and peer-to-peer networks for file sharing. The origins of the Internet date back to research commissioned by the United States federal government in the 1960s to build robust, fault-tolerant communication via computer networks (Stewart (ed), 2000). The primary precursor network, the ARPANET, initially served as a backbone for interconnection of regional academic and military networks in the 1980s. Since 1995 the Internet has tremendously impacted culture and commerce, including the rise of near instant communication by email, instant messaging, telephony (Voice over Internet Protocol or VoIP), two-way interactive video calls, and the World Wide Web (Kirstein, 2012) with its discussion forums, blogs, social networking, and online shopping sites. Common methods of Internet access by users include dial-up with a computer modem via telephone circuits, broadband over coaxial cable, fiber optics or copper wires, Wi-Fi, satellite and cellular telephone technology $(3 \mathrm{G}, 4 \mathrm{G})$.

The right to freedom of expression is recognized as a human right under article 19 of the Universal Declaration of Human Rights and recognized in international human rights law in the International Covenant on Civil and Political Rights (ICCPR). Article 19 of the ICCPR states that "everyone shall have the right to hold opinions without interference" and "everyone shall have the right to freedom of expression; this right shall include freedom to seek, receive and impart information and ideas of all kinds, regardless of frontiers, either orally, in writing or in print, in the form of art, or through any other media of his choice". In practice, however, this fundamental human right is frequently restricted through tactics that include censorship, restrictive press legislation, and harassment of journalists, bloggers and others who voice their opinions. The free communication of ideas and opinions is one of the most precious of the rights of man. Every citizen may, accordingly, speak, write, and print with freedom, but shall be responsible for such abuses of this freedom as shall be defined by law (Arthur, 2008).

John Stuart Mill, In On Liberty (1859), argued that "...there ought to exist the fullest liberty of professing and discussing, as a matter of ethical conviction, any doctrine, however immoral it may be considered" (Stanford Encyclopedia of Philosophy, 2008). Mill argues that the fullest liberty of expression is required to push arguments to their logical limits, rather than the limits of social embarrassment. However, Mill also introduced what is known as the harm principle, in placing the following limitation on free expression: "the only purpose for which power can be rightfully exercised over any member of a civilized community, against his will, is to prevent harm to others" (ibid). By defining the scope of freedom of expression and of "harmful" speech Milton argued against the principle of pre-censorship and in favor of tolerance for a wide range of views (Sanders, K, 2003). Mill argued that truth drives out falsity, therefore the free expression of ideas, true or false, should not be feared. Truth is not stable or fixed, but evolves with time. Mill argued that much of what we once considered true has turned out false. Therefore, views should not be prohibited for their apparent falsity. Mill also argued that free discussion is necessary to prevent the "deep slumber of a decided opinion". Discussion would drive the onwards march of truth and by considering false views the basis of true views could be re-affirmed (ibid). Furthermore, Mill argued that an opinion only carries intrinsic value to the owner of that opinion, thus silencing the expression of that opinion is an injustice to a basic human right. For Mill, the only instance in which speech can be justifiably suppressed is in order to prevent harm from a clear and direct threat. Neither economic or moral implications, nor the speakers own well-being would justify suppression of speech (Warburton, 2009). 
In agreement with Mill is Evelyn Beatrice Hall's biography of Voltaire. She coined the following sentence to illustrate Voltaire's beliefs: "I disapprove of what you say, but I will defend to the death your right to say it" (Boller et al, 1989). Hall's quote is frequently cited to describe the principle of freedom of speech. In the 20th Century, Noam Chomsky states that: "If you believe in freedom of speech, you believe in freedom of speech for views you don't like. Stalin and Hitler, for example, were dictators in favor of freedom of speech for views they liked only? If you're in favor of freedom of speech, that means you're in favor of freedom of speech precisely for views you despise" (Achbar and Wintonick, 1992). Lee Bollinger argues that "the free speech principle involves a special act of carving out one area of social interaction for extraordinary self-restraint, the purpose of which is to develop and demonstrate a social capacity to control feelings evoked by a host of social encounters." Bollinger argues that tolerance is a desirable value, if not essential.

Communication is a fundamental social process, a basic human need and the foundation of all social organization. It is central to the Information Society. Everyone everywhere should have the opportunity to participate and no one should be excluded from the benefits of the Information Society offers (Klang and Murray, 2005). Give me the liberty to know, to utter, and to argue freely according to conscience, above all liberties (Sanders, K, 2003).

\subsection{Online Readers' Comments}

New online technologies have created countless opportunities for citizen participation in the public debate and a potential to influence public opinion. Web 2.0 environments allow mass media audiences to publish their own content, creating a new paradigm of "produsage" with significant consequences on socials practices, media and democratic society itself. More specifically, the emergence of Web 2.0 technologies, which allow users to produce and publish their own content online, has triggered much academic discussion and growing research regarding the potential of these new modes of communication to challenge the domination of established mass media in providing information to the public and shaping the public opinion.

Several scholars have celebrated the development of communication technology as a means to strengthen and broaden democracy. Communication technology enthusiasts contend that the internet can transform democracy by increasing the information flows and allowing individuals to formulate better-informed opinions (Castells, 2001; Katz, 1998; Poster, 1997; Rheingold, 2002), while it also facilitates the creation of discursive spaces where the public can exchange opinions and engage in public deliberation (Dahlberg, 2001). On the other hand, many scholars take a critical stance towards the internet's democratizing potential, arguing that, despite its free and open nature, it leads to a fragmented public space where individual freedom of expression results in polarized and extreme opinions, rather than a public opinion formed according to Habermasian criteria of the critical-rational speech (Sunstein, 2007).

Whereas traditional media readers were limited to writing letters to the editor, an online version of such public forum is available to online news media readers. They can immediately publish their opinions below online news texts. Scholars have labeled such practice in different manners. Among the many genres of audience participation generated by the incorporation of Internet into traditional media, readers' comments in news are the most widely used in online news sites (Reich, 2011: 97; Noci, 2012: 86; Zamith \& Lewis, 2014: 2). At the same time, they are one of most common forms of citizen engagement online, with great potential for public discourse (Weber, 2014: 941), giving the public a medium for expressing their perspectives on current issues (Henrich \& Holmes, 2013: 1) and on matters of public concern. Readers' comments can be therefore understood as civic forums, where citizens exchange ideas and where civic talk can take place. Reader comments that are published below online news texts have specific characteristics: (a) they relate to news texts and can constitute an "intertextuality" between the news texts and comments that other users post below them; (b) they share the same space with the original messages, and are considered "parasitic text"; (c) they are "communicative text[s]," in that they are a response to the published news items; and (d) they are purposive and asynchronous (You et al., 2011, 5).

In this light, readers' comments might be seen as a desirable contribution to journalism and to a healthy democratization of discourse (Singer \& Ashman, 2009: 13). In fact, research not only has shown that online news comments are a dynamic space of ideas and arguments exchange (Silva, 2013: 186) but also that journalists themselves recognize their potential to fulfill deliberative ideals when engaging their audience in the discussion of public issues (Reich, 2011). Comments yield real-time insights into public attitudes on issues, the factors that influence decision making on an issue, and the particular content that most strongly influences these decisions. These comments and responses serve as a gauge of public opinion that is immediate, spontaneous and (presumably) honest. Because comments seem to influence the opinions of other readers the perspectives conveyed in the comments may come to reflect wider public opinion (Lee and Yoon, 2010; Park and Lee, 2007). Given that almost all on-line news articles on major news sites allow for posting of comments, readers can choose to comment on 
those topics that are of greatest personal interest. Hence the volume of comments on a topic may act as an indicator of the relative importance or passion the public has for different issues. Due to the immediacy, anonymity and largely unmoderated nature of comments, comments tend to be more impulsive, shallow and aggressive than traditional forms of audience participation (Reich, 2009), which may mean that the comments are providing a truer insight into people's opinions than those expressed in other contexts. Manosevitch and Walker (2009) suggest that comments "provide more diverse and authentic public deliberation" than traditional letters to the editor. Sooyoung and Youngshin (2009) assert that comments provide a more realistic setting for understanding the public response as opposed to interviews and experimental studies that create artificial contexts for responding to an issue. "Commenters" (Schuth et al., 2007) may also correct what they believe to be misinformation in other comments, provide support or share anecdotes, and provide 'facts' and links to websites with additional relevant content. The back and forth among commenters creates a conversation in which ideas are debated and negotiated. Readers of comments often have the option of indicating whether they agree or disagree with a comment by simply clicking on the agree/disagree links that usually appear with each comment.

Despite this recognition, in practice, several studies have showed that readers' comments might pose several challenges to journalists and newsrooms, due to an array of aspects: quality concerns related to the presence of inappropriate speech, such as hate speech, racism, defamation, abusive comment, incivility, or linguistic errors (Reich, 2011: 103; Olsson \& Viscovi, 2013: 286); the anonymity of the online users, mainly understood as a factor in the uncivil tone of online discourse (Singer \& Ashman, 2009: 16), which may affect a news organization's reputation (Nielsen, 2014: 479); the devaluation of the moderation of readers' comments and related editing tasks as extra-routine work, with a lower professional status than more demanding and qualified tasks like news stories or investigative work (Olsson \& Viscovi, 2013: 290); or the cost-increasing effect and the additional resources required for managing audience participation (Nyirõ et al., 2011: 132). However, in respect to economic considerations within news outlets, readers' comments may bring concrete benefits such as brand-building, userloyalty and boosting website traffic (Vujnovic, 2011: 145), thus possibly attracting advertisers. The challenges identified by news organizations correspond to a certain extent to much the same challenges which have been pointed out by scholars when analyzing online political forums, drawing attention to some aspects that make them particularly vulnerable to disruption: for instance, the monopolization of discourse by particular individuals and groups (Dahlberg, 2001: 13); or verbal attacks and other forms of incivility (Ferreira, 2010: 110).

The Internet is providing increasing opportunities for online journalism involving the public; online reader comment forums represent one of the newest ways for readers to be heard (Santana, 2011). The likelihood is that more and more people will join these forums to debate issues of importance to citizens. Such interactions offer the potential to not only enhance collaborative knowledge generation (Shanahan, 2010), but to study how knowledge is generated and shared.

\subsection{Review of Empirical Studies on Online Readers' Attention to and Utilization of Online Newspapers' Comment Sections}

Today, online readers' comments are the most popular form of user-generated content in online newspapers followed by surveys and forums (Trost\&Schwarzer, 2012, p. 95). Due to its high prevalence and the large number of comments posted this new type of content and its impact on journalists and readers has become of increasing interest for researchers and practitioners alike. Hereby, researchers were most interested in users' motivation to write comments (Chung \&Yoo, 2008; Springer, 2011; Springer, Engelmann, \&Pfafinger, 2015), content analysis of the comments (Baden \& Springer, 2014; Bergt\& Welker, 2013; Neurauter-Kessels, 2011; Weber, 2012), and the impact on journalists work (Domingo, 2011; Singer, 2011).

Several studies across the world were conducted to examine print and online newspaper readership. Most of these studies concentrated mainly on print and online newspaper reading, preferences, popularity, reading time, and interactivity nature of the online newspaper. The findings of Ihlström and Lundberg (2002) revealed that in Swedish, the subscribing readers of the online versions have increased from one forth to more than a half of the readers, while more than $80 \%$ of the readers prefer print edition of the newspaper. Their findings also indicated that the readers are further interested in a multimedia paper edition for the future. This shows that online newspaper is gaining popularity in the newspaper industry in the country. Nguyen and Western (2006) found that "those who relied on the internet the most for news and information still used traditional sources substantially". Traditional media will continue to exist to complement the internet in providing audience's news and information needs.

Similarly De Waal, et al. (2004) argued that online newspapers only partly seem to substitute print newspaper reading, and to a small extent, but they do not reduce other media behaviors. In addition, online versions of newspapers do not seem to be capable of substituting a whole range of information functions of the print versions. 
In Malaysia, despite the internet becoming a major source of news and information in recent years, newspapers still remain as the main and important reading and informative document for the people to rely on (Salman, et al. 2011). According to the findings of Everett (2011), 50.5\% of the readers favored online newspapers, but despite online reading being free, $32.7 \%$ still prefer reading print newspapers to its online counterpart. The study concluded that although the future of newspaper industry is obscure, it is certain that it will include technology. Newspapers are transforming into a news source that consumers want, and are successfully embracing their technological fate.

Abdurraheem, et al. (2012) employed a survey method to examine the future of print media in information age in Nigeria. Their study showed that the internet which houses online newspaper can be seen as a major predictor of the dwindling print newspaper readership in Nigeria, and that online newspaper was significantly the source of news. This means that the effectiveness of the internet changes the pattern of information dissemination and news consumption in Nigeria especially among the youth. The study further revealed that majority of those who read online newspapers do so because of internet access.

In sum, the preceding review suggests that traditional newspapers are now matching the internet news sources in their own game. Meanwhile, the content of both print and online newspapers matters to readers; increasing the quality of content can increase satisfaction while satisfaction has the potential to result in higher reading motivation and vice versa (Obijiofor\& Green, 2001).

Mathew, et al. (2013) conducted a study to examine the level of online newspaper reading in Nigeria. Their findings indicated that majority (78\%) of Nigerians read online newspapers. They concluded that online newspaper is gaining acceptability among Nigerians. On the contrary, Okonofua, G., A. (2012) chose a survey method to examine the level of exposure and satisfaction of internet subscribers to online newspapers among cyber cafés users. His findings revealed that $50 \%$ of the readers read online newspapers frequently and only $7.5 \%$ seldom reads online newspapers. The findings indicated that print newspapers satisfy the news demands of readers more than the online newspapers. It is evident that online newspaper readers also read print newspapers. The findings of Mathew, et al. (2013) indicated that print newspaper industry was experiencing low readership from readers as a result of the introduction of online newspapers, while Ekareafo, et al. (2013) suggests that a key issue in the management of newspapers is the combination of editorial decisions with technical decisions to bring about quality print run.

Whilst most of the respective research has focused on online discussion forums (e.g. Schultz, 2000; Wright \& Street, 2007; Poletta, Chen, \& Anderson, 2009) and blogs (e.g. Koop \& Jansen, 2009; Zhou, 2009; elNawawy\&Khamis, 2011), online readers' comments have received comparatively little attention (Reich, 2011, p. 100). Nevertheless, it became apparent that some shortcomings identified by Dahlberg also hold true for political discussions by the means of comments. With respect to the first two criteria, Richardson and Stanyer (2011) came to a devastating conclusion for the British Guardian Online: "The discussion on Guardian Online was frequently characterized by childish point-scoring, name calling and repeated quotation of prior posts accompanied by rhetorical questions and distorted conclusions" (p. 997).

Nagiller's content analysis of Austrian online comments on a newspaper website showed that more than 60 percent of the comments were emotional and just 36 percent were factual (Nagiller, 2013, p. 99). Furthermore, she found only in four percent of the comments, a focus on consensus in contrast to more than 50 percent conflict-focusing comments (Nagiller, 2013, p. 100). Tsaliki (2002) came to a similar conclusion in her content analysis of online forums in Greece, Britain, Netherlands and Italy: "In some cases, participants did not seem to approach the forum in order to engage in conversation with fellow citizens and exchange opinions. Instead, it looks as if people simply wished to air their own views without being particularly interested in listening to what others had to say" (p. 107).

Hence, it can be assumed that a substantial number of online comment writers use comments as opportunity to speak up and not to discuss with other commentators. Springer (2011) refers to this type of users as self-presenters, which typically are among the heavy-users of a platform (p. 262). Beside these findings from qualitative research regarding motives of use and the above mentioned content analyses, little is yet known about the persons participating in this type of online deliberation. Based on digital divide research it can be assumed, that the exclusion of certain social groups has declined by the means of having access to the internet with the exception of a few groups like seniors (Friemel, 2014).

However, internet access is a necessary but not sufficient condition for participation in online deliberation. Hence, there might be differences between those reading an online newspaper, those who read the comments, and those 
who write comments. People who show a high political engagement online (utter their opinion and engage politically) tend to be men, have an above-average level of education and interest in politics and are significantly younger than the comparable offline-group (Köcher\&Bruttel, 2011, p. 50). The Pew Research Center came to similar results, but couldn't find a gender difference of online news participation (Purcell et al., 2010, p. 45).

\section{Method}

The survey research method was adopted for this study which focused on online readers within the South-South geo-political zone of Nigeria due to the high population of newspaper publishers originating from the zone. The availability and high concentration of internet cafes and hot spots in the selected cities, triggering high population of online newspaper readers, also informed the zone selection. The states that comprise this zone are: Akwa Ibom, Bayelsa, Cross River, Delta, Edo and River states. Newspaper readers resident in Benin City, Calabar, Port Harcourt, Uyo, Warri and Yenagoa were specifically targeted as the study population.

Using the Taro Yamane formula for sample size determination, a sample of 400 was drawn from the study population of $3,915,386$. Through the stratified random sampling technique, those who are resident within the selected cities and within the age brackets of 18-65 years of both sexes were picked. The selected respondents included 250 hundred income earners and pensioners randomly selected from some government and private offices, 100 respondents who were students drawn from higher institutions in the selected cities, and 50 unemployedpersons. A validated questionnaire was used as research instrument and distributed to all 400 respondents.380 copies of questionnaire were returned while 20 copies of questionnaire were not returned or properly completed. This represents a 95 percent response rate. The data generated for the study were synthesized and analyzed using SPSS (Statistical Package for the Social Science) Version 21.

\section{Theoretical Basis}

This study is anchored on the Perception Theory. According to Folarin (2005), perception depends on a complex of variables such as psychological disposition, past experiences, cultural expectations and social relationships. All these result in the selective process, which takes place in a 'stop gate' fashion with selective exposure, selective attention, and selectiveretention. In line with these selective processes, the core assumptions of this study are:

- In selective exposure: Nigerian audiences have to be exposed to the Nigerian newspapers online before they can attend to it. It is also believed that people seek out information that carters for their own interest, while avoiding those that attack their self-image. This determines which papers they subscribe to or read at all.

- In the selective attention: the eye is known to process information much faster than the brain can interpret. The human brain has to select which information to pay attention to in order to avoid confusion. In the case of the online readers, the attention he pays to the news items on the web depends on the relevance of that message to his predispositions. In order words, an individual surfing the net will pay close attention to a new headline that can satisfy his information search.

- In selective perception: each of the readers tends to perceive and then decode communication messages in the light of their previous experiences, and current dispositions and needs. The language we speak and words we use also tend to circumscribe our perception. The type of headline display could also influence an individual perception of the item.

- In selective retention: only that news item that satisfies an individual's curiosity and which makes meaning to the reader can be retained, that is, online readers can remember certain information that agrees with their needs.

It is to this end that one tends to understand why some online readers comment and others do not, or comment after reading the news stories or read the comments before commenting without reading the news stories.

\section{Results}

The distribution in the sample was 15.3\% from Uyo, 13.2\% for Warri, 21.3\% for Port Harcourt, 19.2\% for BeninCity, $17.1 \%$ for Yenagoa, and $13.9 \%$ of respondents were from Calabar. In terms of gender, 59.2\% of them were male while $40.8 \%$ were female. 
By age, 137 respondents who filled the questionnaire were within the age bracket of $18-25(36.1 \%)$; 90 $(23.7 \%)$ were within the age bracket of $26-35 ; 35(9.2 \%)$ were within the ages of $36-45 ; 64(16.8 \%)$ respondents were aged between 45-55 and lastly, 54 (14.2\%)were between 56 and 65 years old.

By occupation, 38.9\% (148)of the respondents were students, 30.3\% (115) were unemployed, $22.6 \%$ (86) of them were income earners and $8.2 \%$ (31) were pensioners.

\section{Research Question 1: Does the right to Freedom of Expression cause Internet users to freely express themselves?}

The following tables show data collected from the answers to questions posed in an attempt to answer the above stated research question.

Table 1: Respondents who use the Internet

\begin{tabular}{|l|r|r|r|}
\hline & Frequency & Percent & \multicolumn{1}{|c|}{ Valid Percent } \\
\hline Yes & 269 & $70.8 \%$ & $70.8 \%$ \\
No & 111 & $22.2 \%$ & $22.2 \%$ \\
Total & 380 & $100 \%$ & $100.0 \%$ \\
& & & \\
& & & \\
& & & \\
& & & \\
\hline
\end{tabular}

Data in the table shows that $269(70.8 \%)$ answered in the affirmative that they use the internet while $111(22.2 \%)$ respondents answered in negation.

Table 2: How often respondents access the Internet

\begin{tabular}{|l|l|r|r|r|}
\hline & & Frequency & \multicolumn{1}{|c|}{ Percent } & \multicolumn{1}{|c|}{ Valid Percent } \\
\hline Regularly & Regularly & 161 & $42.4 \%$ & $42.4 \%$ \\
Occasionally & Occasionally & 130 & $34.2 \%$ & $34.2 \%$ \\
Don't Know & Don't Know & 89 & $23.4 \%$ & $23.4 \% \%$ \\
Total & Total & 380 & $100 . \%$ & $100 . \%$ \\
& & & & \\
\hline
\end{tabular}

This table shows that $161(42.4 \%)$ respondents access the internet regularly; $130(32.4 \%)$ use it occasionally while $89(24.3 \%)$ don't know how often they use the Internet. 
Table 3: Do you express yourself freely on the Internet?

\begin{tabular}{|l|r|r|r|}
\hline u & Frequency & Percent & \multicolumn{1}{|c|}{ Valid Percent } \\
\hline Yes & 163 & $42.9 \%$ & $42.9 \%$ \\
No & 217 & $57.1 \%$ & $57.1 \%$ \\
Total & 380 & $100 \%$ & $100 \%$ \\
& & & \\
& & & \\
& & & \\
\hline
\end{tabular}

Data collected in the table below indicates that $163(42.9 \%)$ respondents say that they express themselves freely on the Internet while 217 (57.1\%) do not.

Table 4: Reasons why respondents express themselves freely on the Internet

\begin{tabular}{|l|r|r|r|r|}
\hline & Frequency & Percent & Valid Percent & $\begin{array}{c}\text { Cumulative } \\
\text { Percent }\end{array}$ \\
\hline Because I have data & 110 & $28.9 \%$ & $28.9 \%$ & 28.9 \\
Because I want to be heard & 79 & $20.8 \%$ & $20.8 \%$ & $20.8 \%$ \\
Because I want to offer my & 37 & $9.7 \%$ & $9.7 \%$ & $9.7 \%$ \\
opinion & & & & \\
Other & 63 & $16.6 \%$ & $16.6 \%$ & $16.6 \%$ \\
Answer not "Yes" & 91 & $23.9 \%$ & $23.9 \%$ & $23.9 \%$ \\
Total & 380 & $100 \%$ & $100 \%$ & $100 \%$ \\
& & & & \\
\end{tabular}

The table shows that 110 respondents express themselves freely because they have the data. 79 do so because they want to be heard; 37, because they want to offer their opinion; 63, gave other reasons why they express themselves freely while 91 of the 380 respondents said their answers weren't yes.

Table 5: Reasons why respondents do not express themselves freely on the Internet

\begin{tabular}{|l|r|r|r|}
\hline & Frequency & \multicolumn{1}{|c|}{ Percent } & \multicolumn{1}{|c|}{ Valid Percent } \\
\hline Because I don't trust the Internet & 125 & $32.9 \%$ & $32.9 \%$ \\
Because I don't have data & 114 & $30.0 \%$ & $30.0 \%$ \\
Other & 24 & $6.3 \%$ & $6.3 \%$ \\
Answer not "No" & 117 & $30.8 \%$ & $30.8 \%$ \\
Total & 380 & $100 . \%$ & $100 . \%$ \\
& & & \\
\hline
\end{tabular}

The table shows that 125 respondents don't express themselves freely because they don't trust the Internet; 114 , because they don't have data; 24, gave other reasons for not expressing themselves on the Internet while 117 said their answer to the question was no.

Findings from all the tables and data collected above show that from the study sample, most of the respondents (217 in number) do not freely express themselves on the Internet even with the Freedom of Expression. It is only a smaller number of 163 that do and this is against the backdrop of 269 respondents who use the internet. So, in 
answer to research question 1, the right to Freedom of Expression does not cause the Internet users to express themselves freely.

\section{Research Question 2: Do online readers read online newspapers?}

The tables that follow show data collected from responses to questions posed in an attempt to determine if online readers read online newspapers.

Table 6:Respondents who read online newspapers

\begin{tabular}{|l|r|r|r|}
\hline & Frequency & Percent & \multicolumn{2}{|c|}{ Valid Percent } \\
\hline Yes & 267 & & $70.3 \%$ \\
No & 113 & & $29.7 \%$ \\
Total & 380 & & $100.0 \%$ \\
& & & \\
\hline
\end{tabular}

From the above table, data collected suggests that 267 respondents read online newspapers while 113 respondents do not.

Table 7:Reasons why respondents read online newspapers

\begin{tabular}{|c|c|c|c|}
\hline & Frequency & Percent & Valid Percent \\
\hline For Information & 124 & $32.6 \%$ & $32.6 \%$ \\
\hline To be Current & 106 & $27.9 \%$ & $27.9 \%$ \\
\hline For Leisure & 13 & $3.4 \%$ & $3.4 \%$ \\
\hline Because I'm Always Online & 37 & $9.7 \%$ & $9.7 \%$ \\
\hline To Pass Time & 41 & $10.8 \%$ & $10.8 \%$ \\
\hline $\begin{array}{l}\text { To read the views on the comment } \\
\text { sections }\end{array}$ & 23 & $6.1 \%$ & $6.1 \%$ \\
\hline Other & 10 & $2.6 \%$ & $2.6 \%$ \\
\hline Answered nothing & 26 & $6.8 \%$ & $6.8 \%$ \\
\hline Total & 380 & $100 . \%$ & $100 . \%$ \\
\hline
\end{tabular}

From the table above, it shows that 124 respondents read the newspapers online for information; 106 , to be current; 13, for leisure; 37, because they are always online; 41, to pass time; 23 to read the views on the comment sections; 10 gave other reasons not listed as why they read while 26 answered nothing in respect to the question. 
Table 8: Respondents who prefer reading online newspapers

\begin{tabular}{|l|r|r|r|}
\hline & Frequency & Percent & Valid Percent \\
\hline Yes & 188 & 188 & 49.5 \\
No & 192 & 192 & 50.5 \\
Total & 380 & 380 & 100.0 \\
& & & \\
& & & \\
& & & \\
\hline
\end{tabular}

Data collected in this table shows that 188 respondents of the total valid population said they preferred reading online newspapers while 192 said that they do not.

Table 9: Reasons why respondents prefer reading online newspapers

\begin{tabular}{|l|r|r|r|}
\hline & Frequency & \multicolumn{1}{|c|}{ Percent } & \multicolumn{1}{|c|}{ Valid Percent } \\
\hline Because it is less in cost & 93 & $24.5 \%$ & $24.5 \%$ \\
Because it looks less cumbersome & 93 & $24.5 \%$ & $24.5 \%$ \\
Because it isn't inconveniencing & 37 & $9.7 \%$ & $9.7 \%$ \\
Other & 10 & $2.6 \%$ & $2.6 \%$ \\
Answered nothing & 147 & $38.7 \%$ & $38.7 \%$ \\
Total & 380 & $100 \%$ & $100 \%$ \\
& & & \\
\hline
\end{tabular}

The table shows that 93 prefer reading newspapers online because it is less in cost; 93, because it looks less cumbersome; 37, because it isn't inconveniencing; 10 gave other reasons why they prefer reading it online while 147 respondents answered nothing.

Table 10:How often respondents read news stories/articles online

\begin{tabular}{|c|c|c|c|}
\hline & Frequency & Percent & Valid Percent \\
\hline Daily & 138 & & $36.3 \%$ \\
\hline Weekly & 88 & & $23.2 \%$ \\
\hline Every Few Weeks & 41 & & $10.8 \%$ \\
\hline Every Few Months & 49 & & $12.9 \%$ \\
\hline Once a Year or Less & 38 & & $10.0 \%$ \\
\hline Never & 13 & & $3.4 \%$ \\
\hline Other & 13 & & $3.4 \%$ \\
\hline Total & 380 & & $100 \%$ \\
\hline
\end{tabular}

From the tables above which show data collected from responses in relation to research question 2 , it was discovered that of the 400 respondents, 267 of them answered in affirmation that they read online newspapers. 
This could be accepted in mind with 269 respondents who use the internet and 188 who prefer reading newspapers online. So, one can say, from the study, that online readers read online newspapers.

\section{Research Question 3:Do online readers comment after reading online newspapers?}

The tables that follow show data collected from respondents' answers to questions posed in an attempt to find out if online newspaper readers comment after reading content.

Table 11:Respondents who comment after reading newspapers online

\begin{tabular}{|l|r|r|r|}
\hline & Frequency & \multicolumn{1}{|c|}{ Percent } & \multicolumn{1}{|c|}{ Valid Percent } \\
\hline Yes & 245 & $64.5 \%$ & $64.5 \%$ \\
No & 135 & $35.5 \%$ & $35.5 \%$ \\
Total & 380 & $100 \%$ & $100 \%$ \\
& & & \\
& & & \\
& & & \\
& & & \\
\end{tabular}

Data collected in the table above shows that 245 respondents comment after reading the newspapers while 135 respondents do not comment.

Table 12:Reasons why respondents comment after reading online newspapers

\begin{tabular}{|l|r|r|r|}
\hline & \multicolumn{1}{|c|}{ Frequency } & \multicolumn{1}{|c|}{ Percent } & \multicolumn{1}{|c|}{ Valid Percent } \\
\hline To talk back to the newspaper & 105 & $27.6 \%$ & $27.6 \%$ \\
houses & & & $35.0 \%$ \\
To interact with other commenters & 133 & $35.0 \%$ & $17.1 \%$ \\
To contribute my idea & 65 & $17.1 \%$ & $20.3 \%$ \\
Answer not "Yes" & 77 & $20.3 \%$ & $100 \%$ \\
Total & 380 & $100 \%$ & \\
& & & \\
\hline
\end{tabular}

Results in the table show that 105 respondents comment because they want to talk back to the newspaper houses; 133 , to interact with other commenters; 65 , to contribute their ideas while 77 of the respondents did not answer yes.

Table 13:Reasons why some respondents do not comment after reading online newspapers

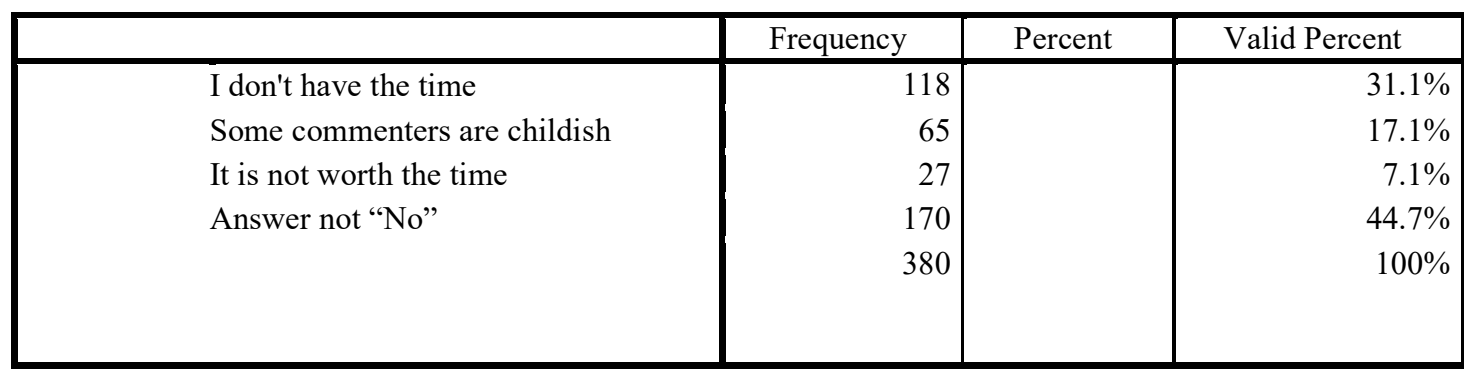


Data collected shows that 118 respondents do not comment after reading because they do not have the time; 65 , because some commenters are childish; 27 , commenting after reading isn't worth the time while the remaining 170 did not answer yes in the first place.

Table 14: How often respondents comment on news stories/articles online

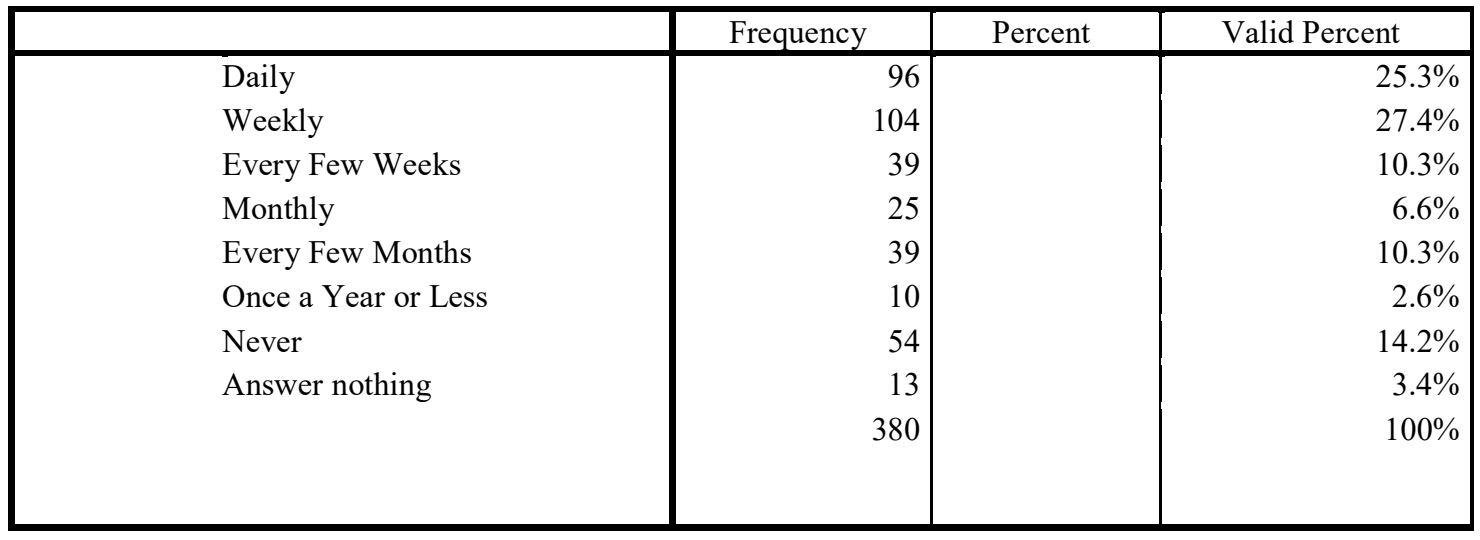

Results show that 96 respondents comment daily on news stories/articles online; 104 weekly; 39, every few weeks; 25 monthly; 39 every few months; 10 once a year or less; 54 never and 13 answered nothing.

Table 15: Respondents who read online news stories/articles before commenting or proceed to comment based on other people's comments that they read

\begin{tabular}{|c|c|c|c|}
\hline & Frequency & Percent & Valid Percent \\
\hline Yes, I read before commenting & 178 & & $46.8 \%$ \\
\hline No, I proceed to comment & 137 & & $36.1 \%$ \\
\hline Answered nothing & 65 & & $17.1 \%$ \\
\hline & 380 & & $100 \%$ \\
\hline
\end{tabular}

The table above shows that 178 respondents read before commenting; 137 said they proceed to comment without reading while 65 answered nothing.

From the study, it was discovered that online readers comment after reading online newspapers because 245 of the 400 respondents answered in affirmation as in line with 178 of them who said they read the newspapers before commenting.

\section{Research Question 4: Are online readers motivated to comment by others' comment?}

Questions posed here were aimed at determining if online readers are motivated to comment by other readers' comments. Data presented in the tables below show their answers to these questions. 
TABLE 16: Respondents who got motivated to comment by others people's comments

\begin{tabular}{|l|r|r|r|}
\hline & Frequency & Percent & \multicolumn{1}{|c|}{ Valid Percent } \\
\hline Yes & 243 & & $63.9 \%$ \\
No & 137 & & $36.1 \%$ \\
Total & 380 & & $100 . \%$ \\
& & & \\
& & & \\
\hline
\end{tabular}

Data in the above table shows that 243 respondents from the population get motivated to comment by others' comment while 137 of the respondents do not.

Table 17: When Respondents usually comment on a story

\begin{tabular}{|c|c|c|c|}
\hline & Frequency & Percent & Valid Percent \\
\hline $\begin{array}{l}\text { When I know something about the } \\
\text { subject that wasn't in the article }\end{array}$ & 94 & $24.7 \%$ & $24.7 \%$ \\
\hline $\begin{array}{l}\text { When I identify with the topic (like an } \\
\text { event I like or a candidate i like or my } \\
\text { political party }\end{array}$ & 90 & $23.7 \%$ & $23.7 \%$ \\
\hline $\begin{array}{l}\text { When I have a personal experience to } \\
\text { add }\end{array}$ & 55 & $14.5 \%$ & $14.5 \%$ \\
\hline When I agree with the author & 28 & $7.4 \%$ & $7.4 \%$ \\
\hline When I disagree with the author & 13 & $3.4 \%$ & $3.4 \%$ \\
\hline When it's a really good story & 10 & $2.6 \%$ & $2.6 \%$ \\
\hline When it's a terrible story & 10 & $2.6 \%$ & $2.6 \%$ \\
\hline Other & 40 & $10.5 \%$ & $10.5 \%$ \\
\hline Answered nothing & 40 & $10.5 \%$ & $10.5 \%$ \\
\hline Total & 380 & $100 \%$ & $100 \%$ \\
\hline
\end{tabular}

Results showed that 94 of the respondents usually comment on the stories when they know something about the subject that wasn't in the story; 90, when they identify the subject discussed in the story; 55, when they have a personal experience to add; 28 , when they agree with the author; 13 , when they disagree with the author; 10 , when the story is really a good one, another 10 , when the story is a terrible one; 40, gave other reasons while the remaining 40, answered nothing.

Findingsin relation to research question 4 show that 243 respondents are motivated to comment by others' comment, which is the bigger number of the whole respondents when divided by their answers on this very question.

In an attempt to discover respondents' other motivations for commenting and/or nor commenting, other questions were posed and the answers are presented in the following tables. 
Table 18: Respondents who are motivated by the phrase "leave a comment" to leave a comment

\begin{tabular}{|l|r|r|r|}
\hline & Frequency & Percent & \multicolumn{2}{|c|}{ Valid Percent } \\
\hline Yes & 189 & $49.7 \%$ & $49.7 \%$ \\
No & 191 & $50.3 \%$ & $50.3 \%$ \\
Total & 380 & $100 \%$ & $100 \%$ \\
& & & \\
& & & \\
& & & \\
\hline
\end{tabular}

From the table, 189 respondents said the phrase "leave a comment" attached to the news stories/articles online, makes them comment while 191 answered that it doesn't motivate them to comment.

Table 19: Respondents' aim in commenting?

\begin{tabular}{|l|r|r|r|}
\hline & Frequency & \multicolumn{1}{|c|}{ Percent } & \multicolumn{1}{|c|}{ Valid Percent } \\
\hline To get my voice heard & 133 & $35.0 \%$ & $35.0 \%$ \\
To correct wrong assumptions & 148 & $38.9 \%$ & $38.9 \%$ \\
To contribute to the production of the & 23 & $6.1 \%$ & $6.1 \%$ \\
news stories & & & \\
Answered nothing & 36 & $20.0 \%$ & $20.0 \%$ \\
Total & & $100 \%$ & $100 \%$ \\
& & & \\
\hline
\end{tabular}

From the table, 133 respondents said when they comment, they are trying to get their voices heard; 148 respondents said they do it to correct wrong assumptions; 23 said it is to contribute to the production of the news stories while 76 answered nothing.

Table 20: Respondents who have come across hate speech, verbal attacks or malicious arguments in the comment sections

\begin{tabular}{|l|r|r|r|}
\hline & Frequency & Percent & \multicolumn{2}{|c|}{ Valid Percent } \\
\hline Yes & 243 & $63.9 \%$ & $63.9 \%$ \\
No & 137 & $36.1 \%$ & $36.1 \%$ \\
Total & 380 & $100 \%$ & $100 \%$ \\
& & & \\
& & & \\
& & & \\
& & & \\
\hline
\end{tabular}

Data collected showed that 243 respondents have come across hate speech, verbal attacks or malicious arguments online while 137 said they never came across such. 
Table 21:Respondents who have initiated or engaged in hate speech, verbal attacks or malicious arguments

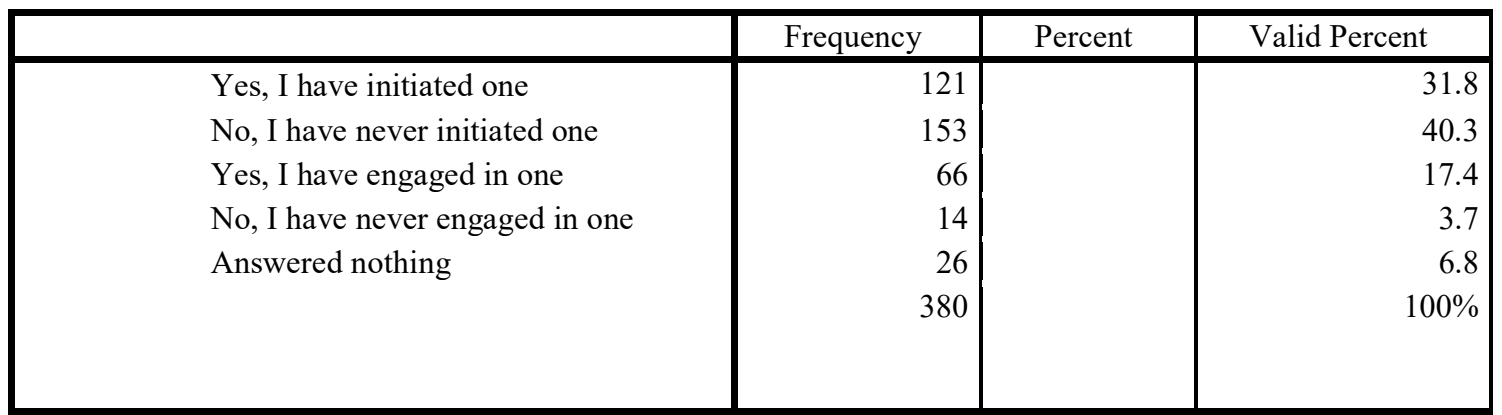

121 respondents answered that they have initiated hate speech, verbal attacks or malicious arguments; 153 said they have never initiated; 66 said they have engaged in hate speech, verbal attacks or malicious arguments; 14 said they have never engaged in one while 26 said nothing.

Table 22: Reasons why respondents initiate or engage in hate speech, verbal attacks or malicious arguments

\begin{tabular}{|l|r|r|}
\hline & Frequency & \multicolumn{1}{|c|}{ Valid Percent } \\
\hline Because I was talked down by commenters & 123 & $32.4 \%$ \\
Because the news story wasn't entirely true & 132 & $34.7 \%$ \\
Because I hate quarrels & 37 \\
Because it isn't the best way to present a point & 35 \\
Answered nothing & 53 & $9.7 \%$ \\
Total & 380 & $9.2 \%$ \\
& & $13.9 \%$ \\
& & $100 \%$ \\
\hline
\end{tabular}

According to the data obtained, 123 respondents said they have initiated or engaged in hate speech, verbal attacks or malicious arguments because they were talked down at by other commenters, 132 did so because the news story wasn't entirely true, 37 said they have never initiated or engaged in one because they hate quarrels, 35 said they haven't because it is not the best way to present a point while 53 answered nothing.

Table 23: Respondents who have been deterred by hate speech, verbal attacks or malicious arguments from commenting

\begin{tabular}{|l|r|r|r|}
\hline & Frequency & Percent & \multicolumn{2}{|c|}{ Valid Percent } \\
\hline Yes & 171 & & $45 \%$ \\
No & 209 & & $55 \%$ \\
Total & 380 & & $100 \%$ \\
& & & \\
& & & \\
& & & \\
\hline
\end{tabular}

171 respondents said hate speeches, verbal attacks or malicious arguments have deterred them from commenting while 209 said they did not. 
Table 24:Respondents who believe newspaper houses take time to go through the comments in comment sections

\begin{tabular}{|l|r|r|r|}
\hline & Frequency & Percent & \multicolumn{1}{|c|}{ Valid Percent } \\
\hline Yes & 183 & & $48.2 \%$ \\
No & 197 & & $51.8 \%$ \\
Total & 380 & & $100 \%$ \\
& & & \\
\hline
\end{tabular}

From the table, 183 respondents said they believe the newspaper houses take the time to go through the comments on the newspapers' comment sections while 197 said they do not believe so.

Table 25: Respondents who are moved by beliefs to keep commenting

\begin{tabular}{|l|r|r|r|}
\hline & Frequency & Percent & \multicolumn{1}{|c|}{ Valid Percent } \\
\hline Yes & 213 & & $56.1 \%$ \\
No & 167 & & $43.9 \%$ \\
Total & 380 & & $100 \%$ \\
& & & \\
\hline
\end{tabular}

Data collected showed that 213 respondents say that their belief cause them to keep commenting while 167 said it doesn't.

Table 26: Respondents position on attention/editing/packaging being paid to online stories as accorded traditional news stories?

\begin{tabular}{|l|r|r|r|}
\hline & Frequency & Percent & \multicolumn{1}{|c|}{ Valid Percent } \\
\hline Yes & 182 & $47.9 \%$ & $47.9 \%$ \\
No & 198 & $52.1 \%$ & $52.1 \%$ \\
Total & 358 & $100 \%$ & $100 \%$ \\
& & & \\
& & & \\
& & & \\
& & & \\
\hline
\end{tabular}

Data in the table above show that 182 respondents think that much attention/editing/packaging is paid to online news stories as accorded the traditional newspapers while 198 said they do not.

\section{Summary and Conclusion}

Based on the findings, it is reasonable to summarize that readers are highly motivated towards reading online version of newspapers particularly in South-South Nigeria. Online newspapers are gaining popularity in the newspaper industry due to certain values they give to the readers such as timely updates and interactivity. This agrees with the findings of Abdurraheem, et al. (2012), Okonofua (2012), Mathew, et al. (2013) and Okonofua (2012) whose findings showed that majority of the respondents were motivated to read online newspapers because they are up to date. Therefore, newspaper publishers should strategize ways to fully embrace their technological fate and enhance quality print run. 
From the foregoing, one can confidently say that we are in an era where the Internet has been embraced by a good number of people. This is seen from the results that show that 269 of 400 respondents use the internet and 163 $(42.9 \%)$ of them also express themselves freely on the Internet. Although a majority (57.1\%) of them do not express themselves freely, this difference may be considered fair enough considering the reasons earlier mentioned in the literature review as well as other reasons indicated by respondents for not expressing themselves freely on the Internet (such as childish talks, anonymity, hate speech, malicious argument, verbal attacks).

A majority (267) of the respondents read and 188 prefer online newspapers. This suggests that online readers actually pay attention to online newspapers and their comment sections. In respect to the utilization of the comment sections, a majority (245) of the respondents comment after reading the online newspapers suggesting that readers make use of the comment sections.We can deduce from this study, in line witharguments proffered by some scholars mentioned in the literature review that the internet has become an interactive sphere for public discourse and the newspapers have embraced such development by inculcating the comment sections. Also, the public want to be part and parcel of what happens around them and contribute to such happenings and because the comment sections have offer them this opportunity, they are utilizing the online comment sections to a great extent.Even as this development is on the rise, we should however not fail to acknowledge the reasons given by some respondents as to their not participating as others do. These reasons include: commenters are childish (according to 65 respondents), news story not entirely true (132 respondents), talked down at by some commenters (123 respondents), came across hate speech, verbal attacks, malicious arguments (243 respondents), deterred from commenting by hate speech and malicious comments (171 respondents), do not believe the newspaper houses go through the comments (197 respondents), belief kept them from commenting (167 respondents) and belief thatlittle attention/editing/packaging is paid to online newspapers as accorded to traditional newspapers.

\section{Recommendations}

Based on the findings of this study, the following recommendations are made:

1. Reading online is different from reading print, therefore, online newspaper editors must find a way to study and understand the differences in the reading patterns of both online and print newspaper readers. It is only through this that they can make online newspapers more convenient for readers. They must develop strategies to sustain readership among their audience by producing quality print run and proper moderation.

3. Online newspaper editors should pay more attention to the quality of reportage available online and give more in-depth analysis of news stories in order to make online newspapers a more dependable source of news for readers.

4. One of the major motivations for readership online is because news is updated faster. Therefore, online newspaper editors must always ensure that breaking news is posted promptly along with accompanying pictures and images.

5. Coverage and content are very important features of online newspapers in motivating readers to visit newspaper websites and online newspaper editors must pay critical attention to this subject matter.

6. More pictures and bolder captions should be used in other contents of online to attract online readers' attention.

7. There is need for the representation of newspaper websites to extend beyond mere presence into an effective utilization and offering of the unique qualities of the Internet - mainly interactivity.

8. Reading online is very dynamic; therefore, regular audience survey must be carried out to ascertain the changes the different target audiences would want implemented. The regular audience survey should be conducted bearing in mind those who exhibit characters, through their comments, that drive others away.

10. It is recommended that for newspaper houses in Nigeria to help regulate the comments, they should find ways to reduce anonymity which would help them trace those who cause trouble through their comments.

\section{References}

Abdulraheem, M., et al. (2012).Information Technology Revolution and the Future of Print Media in Nigeria: Usage Across Age Groups. Advances in Management. A Publication of The Department of Business Administration, University of Ilorin, Ilorin, Nigeria, 10(1), 29-40.

Achbar, M. andWintonick, P. (1992). Manufacturing Consent: Noam Chomsky and the Media. 
Arthur, W. (March 26, 2008). Diamond Law Library at Columbia Law School. Declaration of the Rights of Man and of the Citizen .Retrieved from Hrcr.org (www.hrcr.org).

Article 19. (March 23, 1976). International Covenant on Civil and Political Rights (Office of the United Nations High Commissioner for Human Rights; adopted and opened for signature, ratification and accession by UN General Assembly resolution 2200A (XXI) of 16 December 1966, entry into force 23 March 1976).

Baden, C. and Springer, N. (2014).Com(ple)menting the news on the financial crisis: The contribution of news users' commentary to the diversity of viewpoints in the public debate. European Journal of Communication, 29(5), $529-548$

Bergt, S. and Welker, M. (2013). Online-Feedback alsTeilredaktionellerQualitätsprozesse von Tageszeitungen eineInhaltsanalyse von Leserkommentaren. In C. Fraas, S. Meier, \& C. Pentzold (Eds.), OnlineDiskurse.Theorien undMethodentransmedialerOnlineDiskursforschung(pp. 346-363). Köln: Herbert von Halem.

Bergstrom, A. and Wadbring, I. (2014). Beneficial yet crappy: journalists and audiences on obstacles and opportunities in reader comments. European Journal of Communication - online first. Pp. 1-15.

Bill, S. (ed) (January 2000). IPTO -- Information Processing Techniques Office. The Living Internet.

Büsser, B. (2013). Kommentare von rechts.EditoKlartext(2), 26-27.

Boller, Jr., et al (1989). They Never Said It: A Book of Fake Quotes, Misquotes, and Misleading Attributions. New York: Oxford University Press.

Brett, S. (1999). Limits to tolerance: freedom of expression and the public debate in Chile. Human Rights Watch.p. xxv.

Bridwell Library. (December 17, 2000). The index of expurgations . "Heresy and Error": The Ecclesiastical Censorship of Books, 1400-1800.

Bridwell Library. ( December 17, 2000). Jacobus de VoragineLegendaaurea sanctorum. Madrid: Juan Garcia. In The Index of Expurgations, "Heresy and Error": The Ecclesiastical Censorship of Books, 1400-1800.

Bowman, S. and Willis, C.(2003). We media: How audiences are shaping the future of news and information. Reston, VA, Media Center, American Press Institute.

Castells, M. (2001).The Internet Galaxy.Reflections on the Internet, Business and Society.Oxford University Press.

CFCM TV ( 22 March, 2007). CulteMusulmanet Islam de France. CFCM TV Cho, K.(2007): A study on textual typology of Internet “Daet-geul.” Korean Journal of Text Linguistics, 3, 2, 203-230.

Cho, K.(2007). A study on textual typology of Internet "Daet-geul."Korean Journal of Text Linguistics, 3. 2, 203230 .

Chung, D. (2008). Interactive features of online newspapers: Identifying patterns and predicting use of engaged readers. J. Comput. Mediat. Comm.13. 658-679.

Chung, D. S. and Yoo, C. Y. (2008). Audience Motivations for Using Interactive Features: Distinguishing Use of Different Types of Interactivity on an Online Newspaper. Mass Communication and Society, 11(4), 375-397.

Cook, M. (2011). Guardian.co.uk: online participation, "agonism" and "mutualisation"”. Masters Dissertation submitted to the Department of Media and Communications, London School of Economics and Political Science.

Dahlberg, L. (2001). Democracy via Cyberspace: Mapping the Rhetorics and Practices of Three Prominent Camps. Media, Culture \& Society 3(2): 157-177 
De Waal, E., et al (2004). Online newspapers: a substitute for print newspapers and other information channels?.In 6th World Media Economics Conference, Canada (pp. 12-15).

Domingo, D. (2011). Managing Audience Participation.Practices, Worklows and Strategies. In J. B. Singer, A. Hermida, D. Domingo, A. Heinonen, S. Paulussen, T. Quandt, \& M. Vujnovic (Eds.), Participatory Journalism: Guarding Open Gates atOnline Newspapers (pp. 76-95). Malden, Oxford: Wiley-Blackwell.

Domingo, D. (2015). Fostering and moderating citizen conversations. In L. Zion \& D. Craig (eds.). Ethics for digital journalists: Emerging best practices. NY: Routledge.

Domingo, D., et al (2008). Participatory journalism practices in the media and beyond: An international comparative study of initiatives in online newspapers. Journalism Practice, 2(3), 326-342.

Dorostkar, N. and Preisinger, A. (2013).Kritische Online-Diskursanalyse. MedienlinguistischeunddiskurshistorischeAnsätzezurUntersuchung von Leserkommentarforen.In C. Fraas, S. Meier, \& C. Pentzold (Eds.), OnlineDiskurse.Theorien und MethodentransmedialerOnlineDiskursforschung (pp. 313-345). Köln: Herbert von Halem.

Dragoš, S. (2007).Sovražnigovor.Socialnodelo, 46, 3, 135-144.

el-Nawawy, M. and Khamis, S. (2011). Political Blogging and (Re)Envisioning the Virtual Public Sphere: Muslim-Christian Discourses in Two Egyptian Blogs. International Journal of Press/Politics, 16(2), $234-253$.

Emmer, M., et al (2011).Bürger online. Die Entwicklung der politischenOnlineKommunikation in Deutschland. Konstanz: UVK.

Erjavec, K.(2012): Novinarskoopredeljevanje in razumevanjesovražnegagovora. Teorija in praksa, 49, 1, 95-111. Ekhareafo, D. O., et al (2013). The Challenges of Newspaper Management in Information and Communication Technology Age: The Nigerian Situation. British Journal of Arts and Social Science, 13(1).

Erjavec, K. and Kovacic, M. P. (2013). Abuse of online participatory journalism in Slovenia: offensive comments under news itens. Medij.Istraz, 19 (2), pp. 55-73.

Erjavec, K., and Poler K. M.(2012a). "You Don't Understand, This is a New War!" Analysis of Hate Speech in News Web Sites' Comments. Mass Communication and Society, 15, 6, 899-920.

Erjavec, K., Poler K. M.(2012b). Novinarstvo in internet: znacilnostipiscevsovražnegagovora v komentarjih pod spletniminovinarskimiprispevki. Teorija in praksa, 2012, 49, 1, 190-203.

Everett, C. E (2011).Transformation of Newspapers in the Technology Era.The Elon Journal of Undergraduate Research in Communications, 2 (2), 102.

Ferreira, G. (2010). Internet e deliberação.A discussãopolíticaemfóruns online.Media \&Jornalismo, 16 (1). Pp. 99-114.

Findahl, O. (2008). The Diffusion of the Internet and the Effects on Traditional Media: The case of Sweden and the Nordic Countries. Paper presented to Nordic Media in Theory and Practice, London.

Folarin, B. (2005). Theories of Mass Communication: An Introductory Text (3rd ed.). Ibadan: Bakinfo Publications.

Friemel, T. N. (2014). The digital divide has grown old: Determinants of a digital divide among seniors. New Media \& Society (online first).

Glanville, J. (November 17, 2008). The big business of net censorship. London: The Guardian

Gurevitch, M. et al (2009). Political Communication - old and new media relationships. Annals of the American Academy of Political and Social Science 625, pp.164-181. 
Habermas, J. (1971). VorbereitendeBemerkungenzueinerTheorie der kommunikativenKompetenz. In J. Habermas\& N. Luhmann (Eds.), Theorie derGesellschaftoderSozialtechnologie: Was leistet die Systemforschung? (pp. 101-141). Frankfurt am Main: Suhrkamp.

Hermida, A. and Thurman, N. (2008). A Clash of Cultures: The Integration of User-Generated Content within Professional Journalistic frameworks at British Newspaper Websites. JournalismPractice 2.No. 3.Pp 343-56

Henrich, N. and Holmes, B. (2013). Web news readers' comments: towards developing a methodology for using on-line comments in social inquiry. Journal of Media and Communication Studies. 5 (1), pp. 1-4.

Hille, S. and Bakker, P. (2014).Engaging the social news user.Comments on news sites and Facebook.Journalism Practice, 8 (5). Pp. 563-572.

Hodder, A and Puddephatt, A. (2005).Freedom of Expression, The essentials of Human Rights. pg.128

Human Rights Watch. (August 30, 2006). How Censorship Works in China: A Brief Overview.

Ihlström, C. and Lundberg, J. (2002).The Audience of Swedish Local Online Newspapers: a Longitudinal Study in Technology interactions: Proceedings of the 6th International ICCC IFIP Conference on Electronic Publishing.

Katz, J. (1998). The Netizen: Birth of a Digital Nation. In Holeton, R. (eds.) Composing Cyberspace.Identity, Community and Knowledge in the Electronic Age. Boston: McGraw Hill.

Kirstein, P. T. (25 December 2012). Early experiences with the ARPANET and Internet in the UK.Department of Computer Science, Systems and Networks Research Group, University College London. In Cade Metz . "How the Queen of England Beat Everyone to the Internet". Wired Magazine.

Klang, M. and Murray, A. (2005). Human Rights in the Digital Age .Routledge.P. 1.

Köcher, R., and Bruttel, O. (2011).Social Media, IT \& Society 2011. Retrieved from http://www.infosys.com/de/newsroom/press-releases/documents/socialmedia-it-society2011.pdf

Koop, R. and Jansen, H. J. (2009). Political Blogs and Blogrolls in Canada: Forums for Democratic Deliberation? Social Science Computer Review, 27(2), 155-173.

Lee, E.J. and Yoon, J. J. (2010). What Do Others' Reactions to News on Internet Portal Sites Tell Us? Effects of Presentation Format and Readers' Need for Cognition on Reality Perception.Commun.Res. 37(6).825-846.

Leedy, P.D. and Ormrod, J. E. (2010).Practical research planning and design (9th ed.). Upper Saddle River, NJ: Prentice Hall.

Manosevitch, E. and Walker, D. (2009). Readers' comments to online opinion journalism: A space of public deliberation. 10th International Symposium on On-line Journalism. Austin, Texas.

Mathew, J., et al (2013). Online Newspaper Readership in the North Eastern Nigeria.Asian Journal of Social Science and Humanities, 12 (2).

Matseketsa, B. N. and Mapolisa, T. (2013).The effect of terrorism on international peace and security and educational systems in Africa and beyond - A new millennium perspective".International Journal of Advanced Research.Vol. 1 (8), pp. 694-710.

Marlin, R. (2002). Propaganda and the Ethics of Persuasion . Broadview Press. pp. 226-227.

McCluskey, M. and Hmielowski, J. (2011). Opinion expression during social conflict: Comparing online reader comments and letters to the editor. Journalism.13(3).303-319. 
McKenna, L. and Pole, A. (2008). What do bloggers do: an average day on an average political blog.Public Choice, 134(1-2), 97-108.

Meyer, H. K. and Carey, M. C. (2014).In moderation. Examining how journalists' attitudes towards online comments affect the creation of community. Journalism Practice, 8 (2). Pp. 213-228.

Motl, A.(2010). Sovražnigovor v slovenskihmedijihnaspletuMedijskapreža, 37, 1, 20-21.

Nagiller, J. (2013). Das deliberative Potenzial von Online-Diskussionen auf Nachrichtenportalen. In V. Dander, et al (Eds.), Medienräume: Materialität und Regionalität. Innsbruck: Innsbruck Univ. Press.

NET-Metrix (2014).NET-Metrix-Audit 2014-15. Retrieved from http://netreport.net-metrix.ch/audit/

Nguyen, A. and Western, M. (2006). The Complementary Relationship between the Internet and Traditional Mass Media: The Case of Online News Information. Information Research, 11 (3).

Nielsen, C.(2010). Community conversation or 'the new bathroom wall'?Anonymous online comments and the journalist's role.Presented at the annual meeting of the Association for Education in Journalism and Mass Communication, Newspaper Division. Denver, CO, 4. 8. 2010. http://citation.allacademic.com $/ \mathrm{meta} / \mathrm{p} \mathrm{mla}$ apa research citation/4/3/4/7/7/p434772 index.htm.

Nielsen, C. E. (2014). Coproduction or cohabitation: are anonymous online comments on newspaper websites shaping news content? New Media \& Society, 16 (3). Pp. 470-487.

Noci, J. D. (2012). Mubarak resigns: assessing the quality of readers' comments in online quality media. Trípodos.

Nyirõ, N. et al (2011). Competing by participation - a winning marketing tool.Communication Management Quarterly 21. Pp. 111-140.

Obijiofor, L. and Green, K., (2001). New technologies and future of newspapers, Asia Pacific Media Educator, 1 (11) 88-99.

Ohiagu, O. P. (2011).The Internet: The Medium of the Mass Media. Kiabara Journal of Humanities, 16(2), 225232.

Okonofua, A. G. (2012). Readership of Online Newspapers by Users of Select Cyber Cafés in Uyo Urban.Paper presented at the Pre-Conference of International Federation of Library Association, Mikkeli, Finland.

Okoro, N. and Diri, C. T. (2012).The challenge of Online Newspaper Phenominon to Offline newspaper patronage and Revenue in Nigeria (online). Retrieved from www.academicexcellencesociety.com/jounals.html

Olsson, T. and Viscovi, D. (2013). Impediments to participation: UGC and professional culture. In I. T. Trivundza et al. (eds.). Past, future and change: contemporary analysis of evolving media scapes, Ljubljana: University of Ljubljana Press.

Park, N. and Lee, K. (2007).Effects of Discussions in Online News Forum on Corporate Reputation.Public Relat. Rev. 33(3):346-348.

Patel, A. (2010). The survival of Newspaper in the Digital Age of Communication.Thesis, Leonard N. Stern, New York University, New York.

Papacharissi, Z. (2004). Democracy online: civility, politeness, and the democratic potential of online political discussion groups. New Media \&Society, 6(2), 259-283.

Poletta, F., et al. (2009). Is Information Good for Deliberation? Link Posting in an Online-Forum.Journal of Public Deliberation,5(1), Art. 2.

Poster, M. (1997).Cyberdemocracy: Internet and the Public Sphere. In Holmes, D. (eds.) Virtual Politics.Identity and Community in Cyberspace. London: Sage Publications. 
Purcell, K., et al (2010). Understanding the participatory news consumer.Pew Internet.

Reich, Z. (2009). Weaving the Thread: Gatekeeping and Filtering Strategies for User Comments.Conference Papers - International Communication Association 1.

Reich, Z. (2011). User comments: The transformation of participatory space. In J. B. Singer et al. (eds.). Participatory journalism: Guarding open gates at online newspapers. MA: Wiley-Blackwell

Rheingold, H. (2002). Smart Mobs: The next Social Revolution. Basic Books.

Richardson, J. E. and Stanyer, J. (2011). Reader opinion in the digital age: Tabloid and broadsheet newspaper websites and the exercise of political voice. Journalism, 12(8), 983-1003.

Ryfe, D. (2005). Does deliberative democracy work? Annual Review of Political Science.

$8: 49-71$.

Sanders, K. (2003). Ethics \&Journalism .Sage.P. 66.

Santana, A.(2010). Conversation or cacophony: Newspapers reporters' attitudes toward online reader comments. Presented at the annual meeting of the Association for Education in Journalism and Mass Communication,

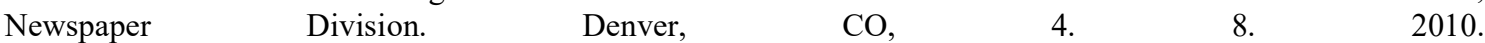
http://citation.allacademic.com/meta/p_mla_apa_research_citation/4/3/4/5/6/p434567_index.html

Santana, A.(2012). Civility, Anonymity and the Breakdown of a New Public Sphere. Unpublished doctoral dissertation:

https://scholarsbank.uoregon.edu/xmlui/bitstream/handle/1794/12420/Santana oregon_0171A 104pdf?sequence $=1$.

Salman, A., et al. (2011). The Impact of New Media on Traditional Mainstream Media.The Innovation Journal, $16(3), 7$.

Saunders, et al (2003).Research Methods for Business Students.(3rd ed). England: Prentice - Hall.

Schultz, T. (2000). Mass media and the concept of interactivity: an exploratory study of online forums and reader email. Media Culture \& Society, 22(2), 205-221.

Schuth A, et al (2007). Extracting the discussion structure in comments on news-articles.9th ACM International Workshop on Web Information and Data Management (WIDM 2007). pp. 97-104.

Shanahan, M (2010). Changing the meaning of peer-to-peer? Exploring online comment spaces as sites of negotiated expertise. J. Sci. Commun.9(1).

Silva, M. T. (2013). Online forums, audience participation and modes of political discussion: readers' comments on the Brazilian presidential election as a case study. Comunicación y Sociedad. 26 (4).175-193.

Singer, J. B. (2011). Taking Responsibility: Legal and ethical issues in participatory journalism. In J. B. Singer, A. Hermida, D. Domingo, A. Heinonen, S. Paulussen, T. Quandt, \& M. Vujnovic (Eds.), Participatory journalism. Guardingopen gates at online newspapers (pp. 121-138). Malden, Oxford: Wiley-Blackwell.

Singer, J. (2014). User-generated visibility: secondary gatekeeping in a shared media space. New Media \& Society, 16 (1), Pp. 55-73.

Singer, J. B. and Ashman, I. (2009). Comment is free, but facts are sacred": user-generated content and ethical constructs at the Guardian. Journal of Mass Media Ethics, 24. pp. 3-21. 
Springer, N. (2011).SucheMeinung, biete Dialog? WarumLeserdieKommentarfunktion auf Nachrichtenportalennutzen. In J. Wolling, A. Will, \& C. Schumann (Eds.), Medieninnovationen(pp. 247-264). Konstanz: UVK.

Springer, N., et al (2015). User comments: motives and inhibitors to write and read. Information, Communication $\&$ Society (online first)

Stanford Encyclopedia of Philosophy. (April 17, 2008). Freedom of Speech

State of the Nation. (January 11, 2015). Retrieved from themillennuimreport.com/2015/01/Charliehebdo-is-notabout-freedom-of-speech-its-about-inciting-world-war-3

Strandberg, K. (2008). Public deliberation goes on-line? An analysis of citizens' political discussion on the Internet prior to the Finnish Parliamentary Elections in 2007.Javnost - The Public, 15(1), 71-90.

Stromer-Galley, J. (2002). New voices in the public sphere: A comparative analysis of interpersonal and online political talk. Javnost - The Public, 9(2), 23-42.

Summer (2006).Using Courts to Enforce the Free Speech Provisions of the International Covenant on Civil and Political Rights . Chicago Journal of International Law 7 (1).

Sunstein, C. R. (2007). Republic.com 2.0.Princeton: Princeton University Press.

Tenenboim, O. and Cohen, A. A. (2013). What prompts users to click and comment: A longitudinal study of online news.Journalism, 20(10), 1-20. Published online before print: December 31, 2013.

Thurman, N. (2008). Forums for citizen journalists? Adoption of user generated content initiatives by online news media. New Media Society 10(1), 139-157

Torres da Silva, M.(2013). Online forums, audience participation and modes of political discussion: readers' comments on the Brazilian presidential election as a case study. Communication \& Society, 26, 4, $175-193$.

Trost, K. E. and Schwarzer, B. (2012).Social Web auf OnlinePortalendeutscherZeitungen.EineempirischeUntersuchung des Nutzungsverhaltens. Baden-Baden:Nomos.

Trygg, S. (2012). Is comment free? Ethical, editorial and political problems of moderating online news.Polis Research Report.London School of Economics.

Tsaliki, L. (2002). Online forums and the enlargement of public space: Research findings from a European Project. Javnost - The Public, 9(2), 95-112.

Universal Declaration on Human Rights (UDHR) adopted by the General Assembly of the United Nations on 10 December 1948.

Vujnovic, M. (2011).Participatory journalism in the marketplace.Economic motivations behind the practices. In J. B. Singer et al. (eds.). Participatory journalism: Guarding open gates at online newspapers. MA: WileyBlackwell. Pp. 139-154.

Warburton, Nigel (2009). Free Speech: A Very Short Introduction. Oxford. pp. 24-29. 63. ^ a b

Wardle, C., et al. (2009). A production study examining the ways in which audience material is used at the BBC. Presented at the annual meeting of the International Communication Association. Chicago, IL, 20. 5. 2009. http://citationallacademic.com/meta/p mla apa research citation/3/0/0/0/5/p300053 index.html

Watts, J. (February 20, 2006). War of the words. London: The Guardian.

Weber, P.(2013). Discussions in the comments section: Factors influencing participation and interactivity in online

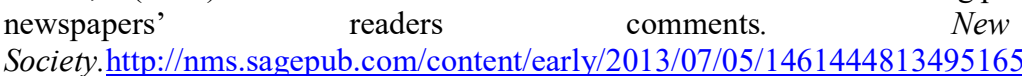


Weber, P. (2012). Nachrichtenfaktoren\& User Generated Content: Die Bedeutung von NachrichtenfaktorenfürKommentierung der politischenBerichterstattung auf Nachrichtenwebsites. Medien\&Kommunikationswissenschaft, 60(2), 218-239.

Weber, P. (2014). Discussions in the comments section: factors influencing participation and interactivity in online newspapers' reader comments. New Media \& Society, 16 (6). pp. 941-957.

Wright, S. and Street, J. (2007). Democracy, deliberation and design: the case of online discussion forums. New Media \& Society, 9(5), 849-869.

You, K., et al (2011) Why Use Online Comments?: Examining the Relationship Among Online Comments, Civic Attitudes, and Participation Intention. Paper presented at the annual meeting of the International Communication Association. TBA, Boston. Http://citation.allacademic.com/meta/p489682 index. html (24. 10. 1. 2014).

Zamith, R. and Lewis, S. C. (2014) From public spaces to public sphere. Digital Journalism, 2 (4). pp. 558-574.

Zhou, X. (2009). The political blogosphere in China: A content analysis of the blogs regarding the dismissal of Shanghai leader Chen Liangyu. New Media \&Society, 11(6), 1003-1022. 